\title{
Neuropsychobiological Evidence for the Functional Presence and Expression of Cannabinoid CB2 Receptors in the Brain
}

\author{
Emmanuel S. Onaivi \\ Department of Biology, William Paterson University, Wayne, N.J., USA
}

\section{Key Words}

CB2 cannabinoid receptor $\cdot C B 2$ gene $\cdot C B 2$ polyclonal antibody $\cdot$ CB2 knockout mice $\cdot$ CB2 electron micrograph from brain neurons

\begin{abstract}
For over a decade, until recently, it was thought that marijuana acts by activating brain-type cannabinoid receptors called CB1, and that a second type called CB2 cannabinoid receptor was found only in peripheral tissues. Neuronal CB2 receptors in the brain had been controversial. We reported the discovery and functional presence of CB2 cannabinoid receptors in the mammalian brain that may be involved in depression and drug abuse and this was supported by reports of identification of neuronal CB2 receptors that are involved in emesis. RT-PCR, immunoblotting, hippocampal cultures, immunohistochemistry, transmission electron microscopy, and stereotaxic techniques with behavioral assays were used to determine the functional expression of CB2 cannabinoid receptors in the rat brain and mouse brain exposed to chronic mild stress or treated with abused drugs. RT-PCR analyses supported the expression of brain CB2 receptor transcripts at levels much lower than those of CB1 receptors. In situ hybridization revealed CB2 mRNA in cerebellar neurons of wild-type but not of CB2 knockout mice. Abundant CB2 receptor immunoreactivity (iCB2) in neuronal
\end{abstract}

\section{KARGER}

Fax +41613061234 E-Mail karger@karger.ch www.karger.com

\section{(C) 2006 S. Karger AG, Basel}

Accessible online at: www.karger.com/nps and glial processes was detected in the brain. The effect of direct CB2 antisense oligonucleotide injection into the brain and treatment with $\mathrm{JWH} 015$ in motor function and plusmaze tests also demonstrated the functional presence of CB2 cannabinoid receptors in the central nervous system. In humans, there was a high incidence of Q63R polymorphism in the CB2 gene in Japanese alcoholics and depressed subjects. Contrary to the prevailing view that CB2 cannabinoid receptors are restricted to peripheral tissues and predominantly in immune cells, we demonstrated that CB2 cannabinoid receptors and their gene transcripts are widely distributed in the brain. This multifocal expression of iCB2 in the brain suggests that CB2 receptors may play broader roles than previously anticipated and may therefore be exploited as new targets in the treatment of depression and substance abuse.

Copyright $\odot 2006$ S. Karger AG, Basel

\section{Introduction}

Research on the molecular and neurobiological basis of the physiological and neurobehavioral effects of marijuana and cannabinoids has lagged behind research on other natural addictive products like opium and tobacco, because of a lack of specific molecular tools and technology. Now significant and rapid progress has transformed

Emmanuel S. Onaivi, PhD

Department of Biology

William Paterson University

Wayne, NJ 07470 (USA)

Tel. +1 973720 3453, Fax +1 973720 2338, E-Mail Onaivie@wpunj.edu 
marijuana-cannabinoid research into mainstream science with the cloning of genes encoding cannabinoid receptors and the generation of cannabinoid receptor knockout mice.

There are two currently well-characterized cannabinoid receptors, $\mathrm{CB} 1$ and $\mathrm{CB} 2$, with functional evidence for the existence of other subtypes, whose identities have been elusive. But these unknown subtypes may turn out to be splice variants of $\mathrm{CB} 1$ or $\mathrm{CB} 2$ receptor subtypes. The effects of cannabinoid and marijuana use are mediated by activation of cannabinoid receptors. CB1 receptors were serendipitously discovered [1] while characterizing an orphan receptor that turned out to be CB1 cannabinoid receptor, which is now known to be one of the most abundant binding sites in the brain [2]. The CB1 receptors are expressed primarily in the brain and some peripheral tissues, while the $\mathrm{CB} 2$ receptors were thought to be expressed primarily by immune cells [3] in peripheral tissues. After over a decade, definitive identification and functional characterization of neuronal CB2 cannabinoid receptors was also serendipitous.

During the summer of 2004, we were interested in evaluating the involvement of cannabinoid receptors in depression, motivated by the self-medication hypothesis of drug abuse. Because it was believed that only CB1 receptors are expressed in the brain, we wanted to measure CB1 protein expression in the brains of stressed mice in comparison to controls. As CB1 receptor antibodies were back-ordered, we ordered the available CB2 receptor antibodies, since we had postulated several years back that CB2 receptors are expressed in the brain but not well characterized. We identified and reported the functional presence and expression of peripheral cannabinoid CB2 receptors in the brain [4-11] at several scientific conferences in abstract form and as a book chapter [12].

While abundant $\mathrm{CB} 1$ receptors are likely to represent the principal brain sites for action of endogenous and exogenous cannabinoids, a number of lines of evidence support possible brain roles for $\mathrm{CB} 2$ and other as yet unidentified cannabinoid receptors. CB2 cannabinoid receptors are particularly enriched in immune tissues [13-15], leading to the expectation that they are present in $\mathrm{mi}-$ croglia. A number of laboratories failed to detect the presence of CB2 in healthy brains [14, 16-21]. Other groups have demonstrated CB2 expression in rat microglial cells [22], in cerebellar granule cells [23], in mast cells [24, 25], in retinal tissue [26], in human astrocytes [27], in limited populations of microglial cells including plaque-associated glia in Alzheimer's disease brains [28-30], and in human brain capillary and microvessel preparations [31].
CB2 receptor expression is induced in the macaque brains by simian immunodeficiency virus infection [28] and in rat spinal cord in neuropathic but not inflammatory chronic pain models $[29,30,32,33]$. Despite this evidence that $\mathrm{CB} 2$ receptors might be present in the central nervous system (CNS), the expression of neuronal CB2 cannabinoid receptors in the CNS has been much less well established and characterized in comparison to the expression of abundant brain CB1 receptors.

The availability of anti-CB2 affinity-purified polyclonal antibodies directed against amino acids 1-33 and 20-33 of the CB2 N-terminus and a C-terminal CB2 receptor antibody provided an opportunity to study the brain expression of CB2 immunoreactivity (iCB2) using light and electron microscopy that can be documented in neuronal patterns. In previous studies and even now the specificity of the available antibodies against both CB1 and CB2 cannabinoid receptors has been questionable. This is perhaps why many investigators who may have observed the presence of CB2 receptors in the brain concluded that it was probably an artifact. Nevertheless, we reported the discovery and functional characterization of brain cannabinoid CB2 receptors using RT-PCR, immunoblotting, hippocampal cultures, immunohistochemistry, and stereotaxic techniques with behavioral assays. This allowed us to determine the functional expression of $\mathrm{CB} 2$ cannabinoid receptors in the rat brain and mice brain exposed to chronic mild stress (CMS) or those treated with abused drugs. The CMS model of depression which we have previously used [34] has high validity [35]. CB2 immunostaining observed immunohistochemically in apparent neuronal and glial processes in a number of brain areas can be blocked by preadsorbing the sera and is absent from CB2 knockout mice. These observations receive support from in situ hybridization, Western blot, RT-PCR data and transmission electron microscopy which are consistent with multifocal neuronal iCB2 expression in the brain, albeit at more restricted patterns and at much lower levels than those previously reported for $\mathrm{CB} 1$ receptors.

\section{Methods}

Subjects

Male and female C57BL/6, DBA/2 and BALBc mouse strains were utilized in different treatment groups for behavioral tests. $\mathrm{BALBc}$ mice were exposed to CMS every day for 4 weeks to simulate the symptoms of anhedonia; brains from stressed, capsaicinexposed and control mice were prepared for CB2 gene expression assay using RT-PCR, immunohistochemical and electron micros- 
copy. Experiments conformed to the National Institutes for Health guidelines for the care and use of laboratory animals that sought to minimize both the number of animals used and any suffering that they might experience.

\section{Behavioral Measurements and CMS}

A total of $60 \mathrm{BALB} / \mathrm{c}$ male mice were housed $12 \mathrm{~h}$ in the light and $12 \mathrm{~h}$ in the dark. Thirty experimental mice were exposed to CMS every day for 4 weeks to achieve anhedonia (CMS test). These experimental animals were subjected to the weekly CMS regime consisting of three 10 -hour periods of $45^{\circ}$ cage tilt; 3 periods of overnight stroboscopic illumination; two 10-hour periods of empty water bottle; 2 periods of overnight food or water deprivation; two 10-hour periods of damp bedding. The CMS-treated and nonstressed groups consisted of 30 mice each and were split into three subgroups, respectively. The first group was subjected to chronic daily administration of the CB2 agonist JWH015 receiving the selected dose of $20 \mathrm{mg} / \mathrm{kg}$ ( $\mathrm{n}=10$ each). The second group received acute injections of $20 \mathrm{mg} / \mathrm{kg}$ of the CB2 agonist JWH015 ( $\mathrm{n}=10 \mathrm{each}$ ). Doses used were determined from our preliminary studies. The third group was not subjected to injections ( $\mathrm{n}=10$ each). All nonstressed groups were given food and water at all times, as well as comfortable cage surroundings, while the experimental group was housed in a different room. At the end of the stress regime, stereotype behavior was measured in activity monitors in all groups. In addition, stereotype behavior was also measured following acute 10-min treatments with JWH015 (1-20 $\mathrm{mg} / \mathrm{kg}$ ) in naïve male and female mouse strains used. In this test situation, $10 \mathrm{~min}$ after drug administration mice were placed in activity monitors and stereotypic counts obtained from the automated system. Such stereotypic counts like rearing behavior and other repetitive behaviors are automatically recorded by the computer-controlled measurement of motor behavior.

\section{CB2 Cannabinoid Receptor Gene Expression}

CB2 gene expression using RT-PCR was determined in the naive mouse strains, those exposed to CMS and those that were prenatally exposed to capsaicin. Brains were dissected from these groups of mice ( $n=5$ per group). RNA was extracted using RNeasy kit and cDNA was synthesized by Revertra Ace and oligo-dT primer. The expression of Cnr2 gene was compared by TaqMan real-time PCR with an ABI PRISM 7900 HT Sequence Detection System (Applied Biosystems, Foster City, Calif., USA), using the TaqMan gene expression assay for Cnr2 (Mm0043826_m1).

\section{Immunohistochemistry and Electron Microscopy}

Mice were anesthetized with pentobarbital, briefly perfused transcardially with saline and then with $4 \%$ paraformaldehyde in phosphate buffer $(0.1 \mathrm{M}, \mathrm{pH} 7.4)$ for $5 \mathrm{~min}$. Brains were dissected, postfixed in buffered paraformaldehyde for $2 \mathrm{~h}$ at room temperature, equilibrated with $30 \%$ sucrose in phosphate buffer at $4^{\circ} \mathrm{C}$, frozen and cut into sagittal 20 - to 40 - $\mu \mathrm{m}$ sections using a sliding microtome. Immunohistochemistry used floating sections and an avidin-biotinylated peroxidase method. Sections were incubated with $1 \%$ hydrogen peroxide in phosphate-buffered saline for $10 \mathrm{~min}$ at room temperature to inhibit endogenous peroxidase, washed three times with phosphate-buffered saline, incubated for $1 \mathrm{~h}$ in $3 \%$ normal goat serum in Tris-buffered saline, $\mathrm{pH} 7.4$ at $22^{\circ} \mathrm{C}$, incubated in primary CB2 antibody obtained from SigmaAldrich, Mo., USA, and Cayman Chemicals, Mich., USA, diluted
1:300 in Tris-buffered saline containing $3 \%$ normal goat serum for $24 \mathrm{~h}$ at $4{ }^{\circ} \mathrm{C}$, rinsed, incubated for $1 \mathrm{~h}$ at $22^{\circ} \mathrm{C}$ in $1: 200$ dilution of biotinylated goat anti-rabbit (Vector, Burlingame, Calif., USA), rinsed, incubated with $\mathrm{ABC}$ reagent for $1 \mathrm{~h}$ (Vector), rinsed, and then incubated with diaminobenzidine for color deposition. Sections were mounted on coated slides, dehydrated, coverslipped, viewed and imaged using Zeiss and Leitz microscopes and a Nikon digital camera, immunoreactive elements were plotted onto the atlas depictions of Franklin and Paxinos [36], and images edited using Photoshop (vCS; Adobe systems). As additional control, iCB2 of brain sections from CB2 receptor knockout mice and wild-type controls was also analyzed using the C-terminal CB2 receptor antibody obtained from Santa Cruz Biotechnology Inc. (Santa Cruz, Calif., USA).

For electron microscopy, perfusion of the mouse and removal of the brain with $4 \%$ paraformaldehyde, $0.1 \%$ purified glutaraldehyde fixative in $0.1 \mathrm{M}$ phosphate buffer was used for the detection of $\mathrm{CB} 2$ cannabinoid receptors. After tissue preparation, CB2 antibodies were utilized as in immunohistochemical localization with modifications for transmission electron microscopy.

\section{Statistical Analysis}

Data for stereotypy were analyzed by analysis of variance for multiple comparisons, followed by Tukey's test where appropriate. The accepted level of significance was $p<0.05$.

For $C B 2$ gene expression analysis, the unpaired test (GraphPad software) was used and $p<0.05$ was the accepted level of significant difference.

\section{Results}

\section{Analysis of Stereotype Behavior}

There was a general pattern of reduced stereotype behavior following the acute treatment with the CB2 agonist (JWH015, $20 \mathrm{mg} / \mathrm{kg}$ ) in a strain- and gender-dependent fashion. The reduced stereotypy in both males and females in the three mouse strains tested occurred as the dose was increased up to $20 \mathrm{mg} / \mathrm{kg}$ dose (fig. 1). However, there was an enhanced stereotypy in the males and a reduction in stereotype behavior in the females of the $\mathrm{DBA} / 2$ strain. The enhanced stereotype behavior recorded in the DBA/2 males occurred at the lower doses of the agonist (fig. 1).

Control mice displayed significantly more stereotypic activity compared to the control mice chronically treated with JWH015 (20 mg/kg). However, there was no significant difference in stereotype behavior when compared to the stressed group. The stressed acutely treated mice had a significant decrease in stereotypy when compared to the stressed group that was not treated. Acutely treated mice in the control and stress groups displayed slightly less stereotype behavior than the untreated mice (fig. 2). 
Fig. 1. Modification of mouse stereotype behavior by the putative $\mathrm{CB} 2$ cannabinoid receptor agonist JWH015, as assessed in activity monitors. Groups of male and female mice were acutely treated with JWH015 (1-20 mg/kg) for $10 \mathrm{~min}$ prior to placement in activity monitors and stereotypy was evaluated for $20 \mathrm{~min}$ and compared to vehicle-treated animals. Data represent the mean + SEM for 6-10 mice per group. Significant changes in stereotype behavior are indicated as ${ }^{*} \mathrm{p}<0.05$ (one-way ANOVA followed by Dunnett's test for multiple comparison with controls). Groups of male and female mouse strains: C57BL/6 (a and b), BALBc (c and d), DBA/2 (e and f).

Fig. 2. Modification of mouse stereotype behavior by the putative CB2 cannabinoid receptor agonist JWH015 (20 mg/kg), as assessed in activity monitors in stressed and nonstressed mice. Groups of stressed and nonstressed controls were chronically treated and other nontreated stressed and nonstressed groups were acutely challenged with $20 \mathrm{mg} / \mathrm{kg}$ JWH015. C = Controls; $\mathrm{CT}=$ controls chronically treated; $\mathrm{S}=$ stressed group; $\mathrm{ST}=$ stressed animals chronically treated with JWH015; CA and $\mathrm{SA}=$ control or stressed animals acutely treated with $20 \mathrm{mg} / \mathrm{kg}$ JWH015. Stereotype behavior was evaluated for $20 \mathrm{~min}$ and compared to vehicle-treated animals. Data represent the mean + SEM for 6-10 mice per group. Significant changes in stereotype behavior is indicated as ${ }^{*} \mathrm{p}<0.05$ (one-way ANOVA followed by Dunnett's test for multiple comparison with controls).
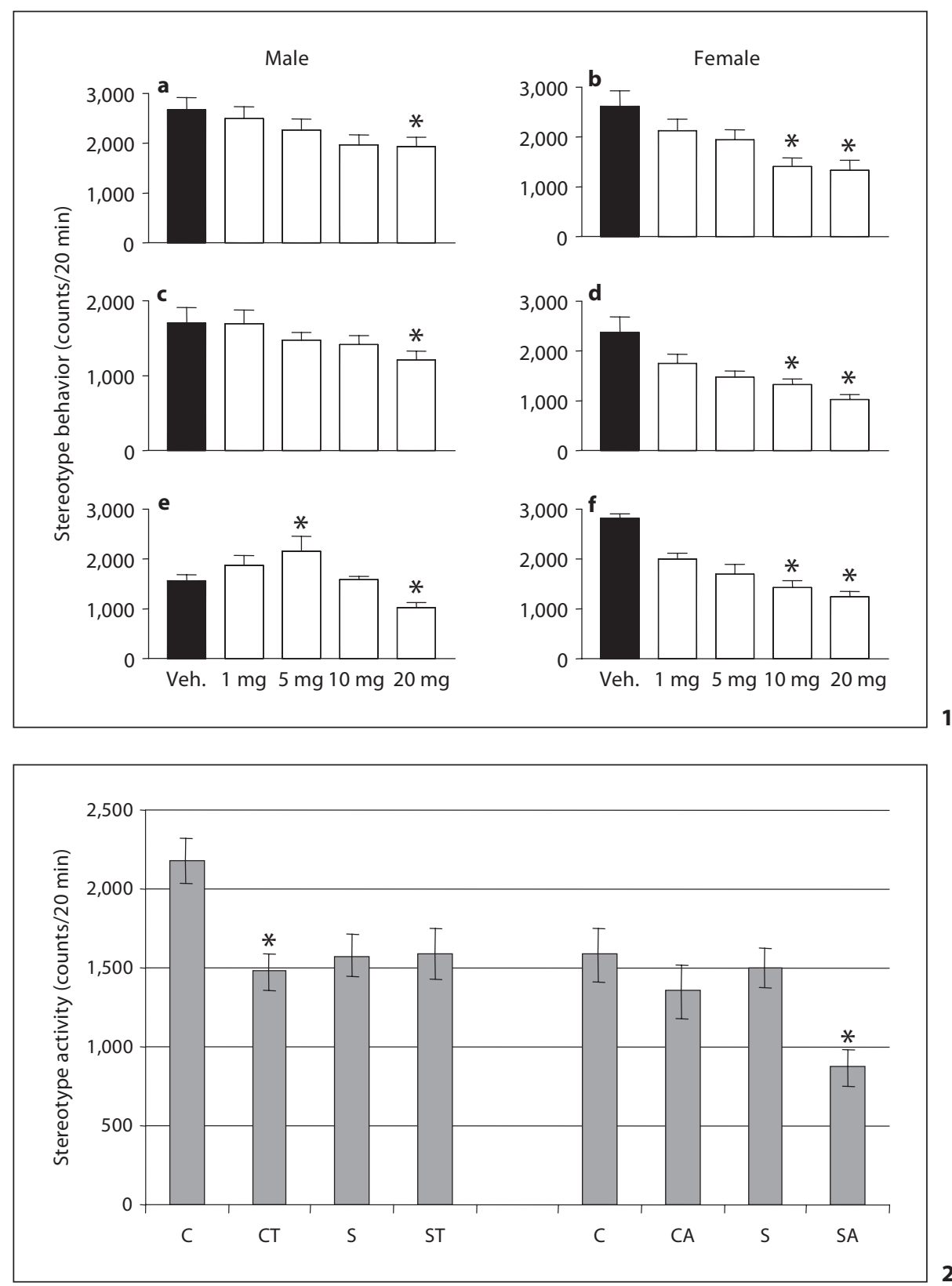

\section{CB2 Gene Expression Analyses}

The expression of the $C B 2$ gene transcripts was present and varied between the whole brains of the three mouse strains BALBc, DBA/2 and C57BL/6 using CB2-specific probes and primers. However, the $C B 2$ gene expression variation was not statistically significant between the mouse strains. Furthermore, the expression of the CB2 gene transcripts was enhanced by CMS and in mice prenatally exposed to capsaicin but this was not statistically significant either (fig. 3).

\section{CB2 Receptor Immunohistochemistry and Electron Micrograph}

CB2-immunopositive staining was observed in the analyzed regions of the cerebral cortex (fig. 4). Apical dendrites of pyramidal neurons were moderately to heavily stained. Other less heavily stained neurons and many blood cells did not show immunostaining. Moderate to dense CB2 immunostaining was observed in pyramidal neurons of the hippocampal allocortex and some interneurons in the stratum oriens and stratum radiatum as 
Fig. 3. Relative quantification of $C B 2$ mRNA expression in the mouse model; the $C B 2$ gene was present and was regulated insignificantly by chronic mild stressors in the whole mouse brain. Brains were obtained from adult C57BL/6 mice that had been prenatally exposed to capsaicin, as well as from adult BALBc mice and another group of C57BL/6 mice exposed to CMS as described in the methods section. The expression of CB2 mRNA in the whole brains of the stressed animals was compared to that of naïve controls. Error bars represent SEM.

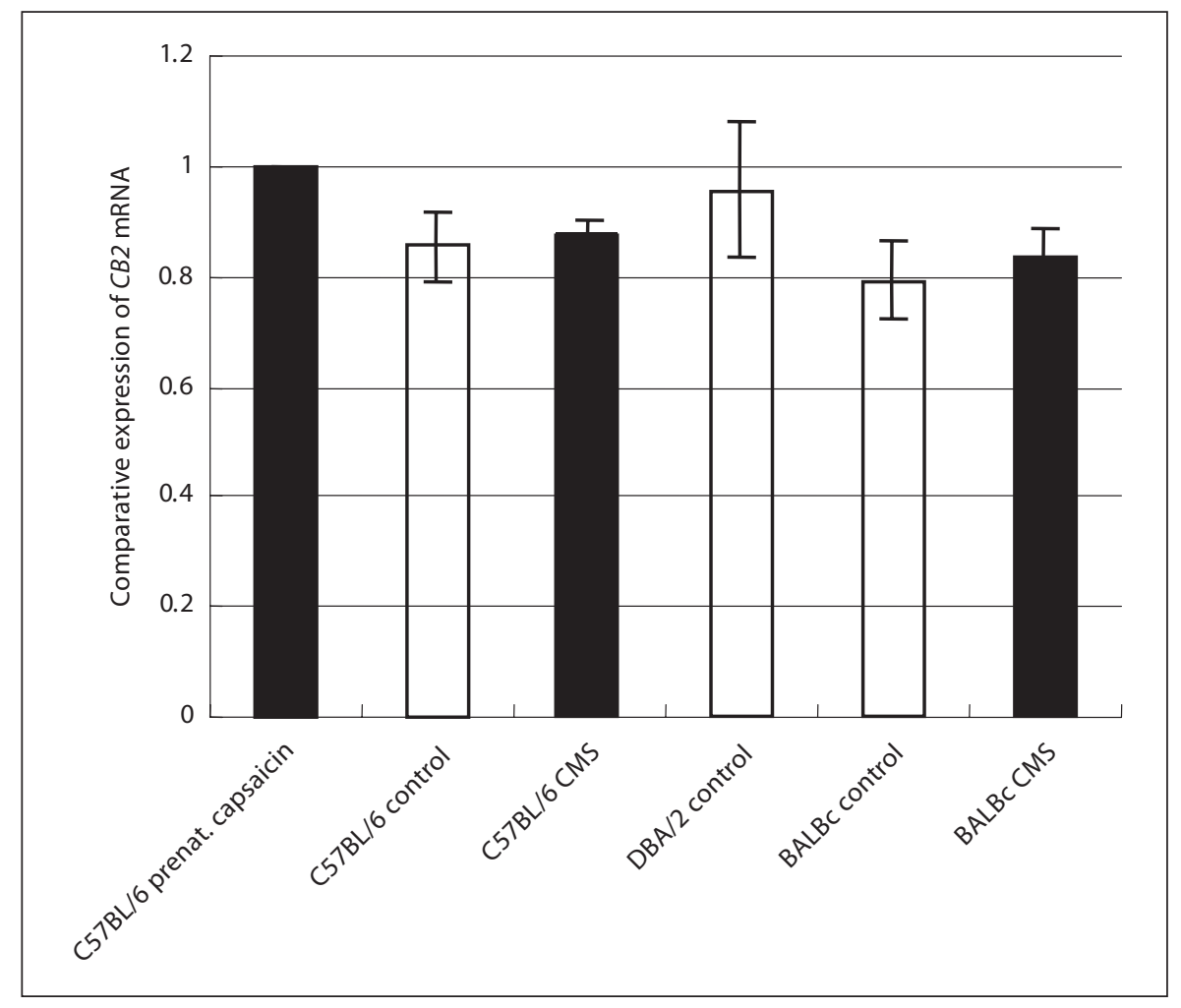

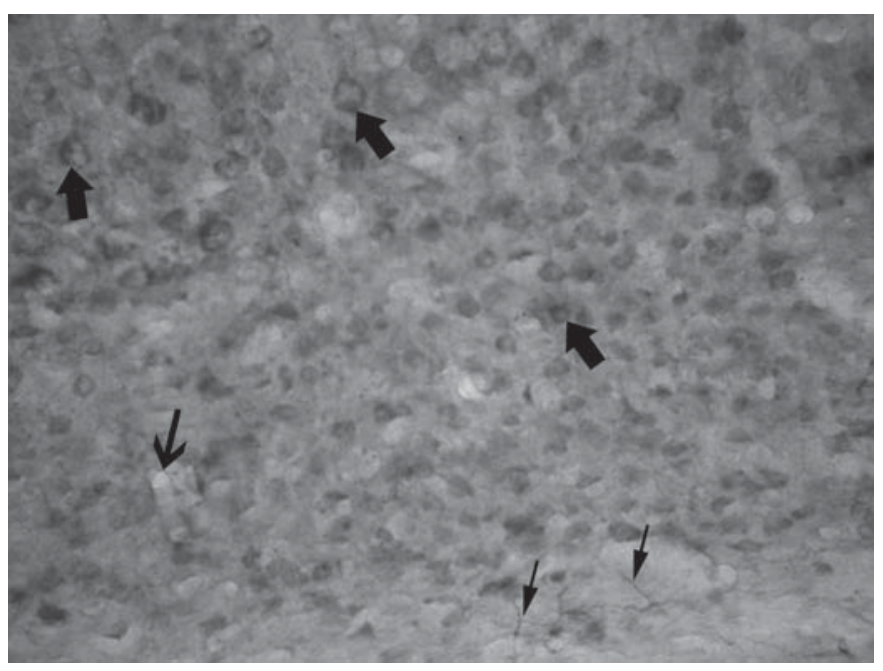

Fig. 4. $\mathrm{CB} 2$-immunopositive staining was observed in the regions of the cerebral cortex that we analyzed. Apical dendrites of pyramidal neurons were moderately to heavily stained. $\mathrm{iCB} 2$ was present mainly in neuronal cell bodies and observed in scattered fibers in the cerebral cortex. In the cerebral cortex, some of the neurons immunostained for CB2 seem to be pyramidal neurons in layers III and V. Other less heavily stained neurons and many blood cells do not show immunostaining because the circulatory system was washed before perfusion. Immunostaining for CB2 has been indicated by arrows.

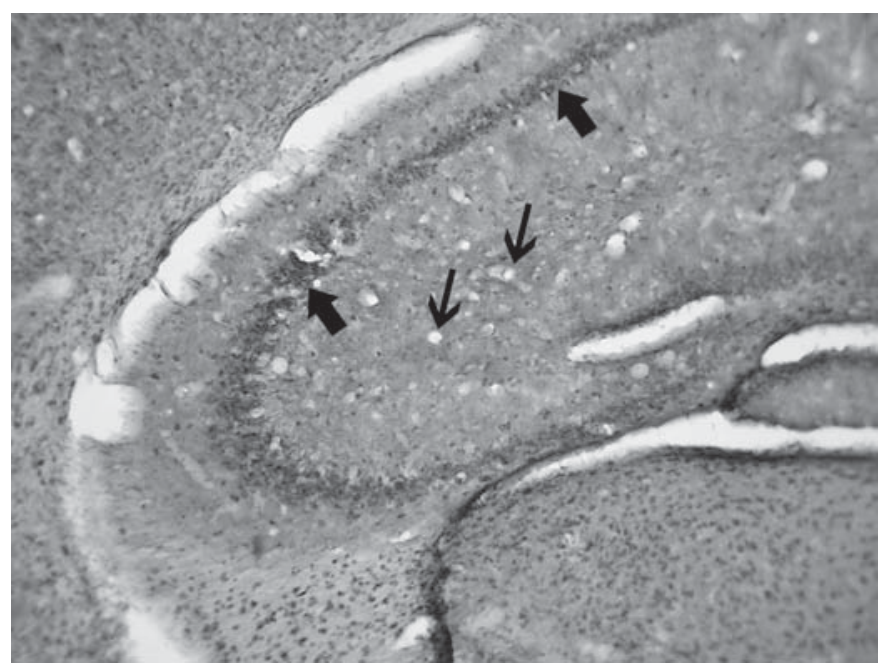

Fig. 5. A moderate to dense CB2 immunostaining was observed in pyramidal neurons of the hippocampal allocortex and some interneurons in the stratum oriens and stratum radiatum. In the hippocampus, the immunostaining is present in the pyramidal layer but also in some interneurons. Some glial cells also appeared to be immunostained for $\mathrm{CB} 2$ in the hippocampus. Immunostaining for CB2 has been indicated by arrows. There are no blood cells present in the tissue because the circulatory system was washed before perfusion. 
Fig. 6. Ultrastructural and subcellular localization of CB2 receptors in mouse cortical neurons. Transmission electron micrograph illustrating a high-resolution definition of cortical CB2 cannabinoid receptor localization at the ultrastructural level. Representative micrograph of the cortical area showing dendrites with immunostaining for CB2 receptors with diffuse black deposits and mitochondria are clearly visible. In some areas, axon terminals were not immunoreactive for CB2 receptors and small rounded synaptic vesicles are present. Two axon terminals making contact with a dendrite but without immunostaining for $\mathrm{CB} 2$ are apparent. For example at the area of the two synaptic contacts, the synapses appear to be excitatory and possibly glutamatergic. The primary magnification is $\times 10,000$. Arrows show asymmetrical synaptic contacts and the diffuse dark DAB deposits indicating positive immunostaining for $\mathrm{CB} 2$ receptors. The star shows a nerve terminal.

indicated in figure 5. Some glial cells also appeared to be immunostained for CB2 in the hippocampus (fig. 5).

There was dense immunostaining for $\mathrm{CB} 2$ receptors with diffuse black deposits on dendrites from mouse brain cortical areas as indicated in the electron micrographs. In some areas, axon terminals were not immunoreactive for $\mathrm{CB} 2$ receptors and small rounded synaptic vesicles were seen (fig. 6). The pattern of staining in most cortical areas appears to be mainly postsynaptic localization of CB2 cannabinoid receptors.

\section{Discussion}

The clinical and functional implication of neuronal CB2 cannabinoid receptors in the brain will gradually become clearer because more research will unravel additional role(s) as hypothesized in this paper. Accumulating evidence from our studies and those of others indicates that CB2 cannabinoid receptors are present in the brain but have not been systematically characterized. The main goal of these studies was to localize CB2 cannabinoid receptors and their distribution patterns in the rat and mouse brains and to assess their functional implication. Some of the data obtained from this ongoing research have been published recently [12] and also presented at scientific conferences [4-11]. Numerous previous studies for over a decade since the cloning of CB2 cannabinoid receptors failed to detect the presence of

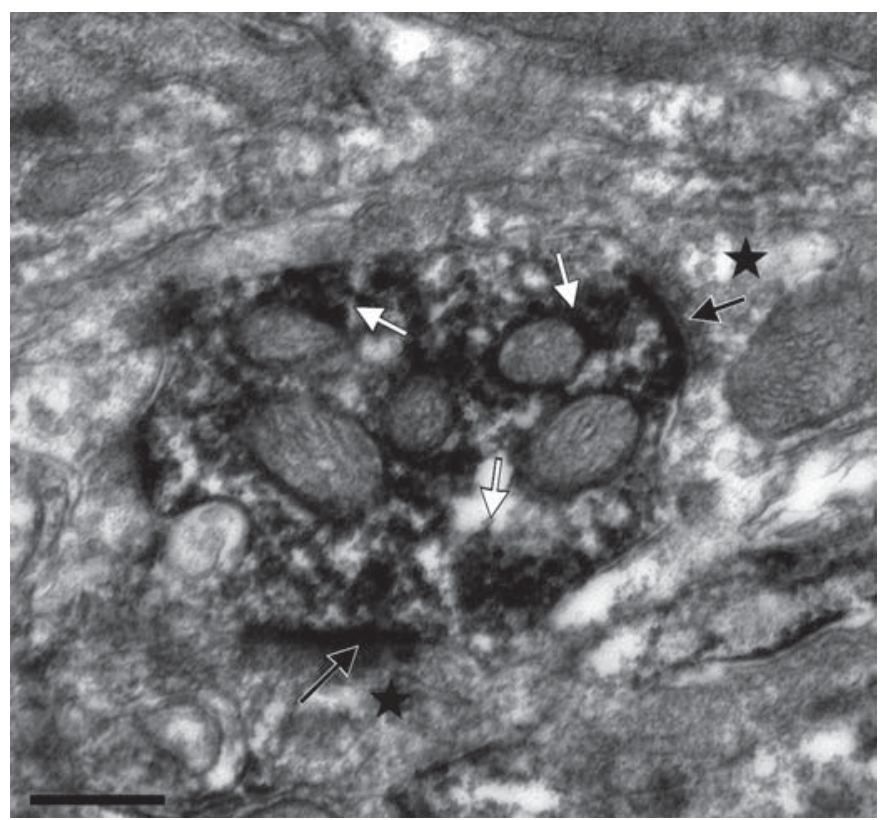

CB2 cannabinoid receptors in the brain [3, 14, 16-20]. Therefore, little was known about their neuronal function. With the availability of specific probes and primers, we detected the presence of $C B 1$ and $C B 2$ mRNAs in the brains of rats and mice using RT-PCR [4-12]. We demonstrated that $\mathrm{CB} 2$ receptors are present in various regions of the adult rat and mouse brains. There were similar patterns of immunostaining in the spleen and cerebellum using three different antibodies. Furthermore, in primary hippocampus cultures, CB2-positive expression was detected in neuron-specific enolase (NSE)-positive cells. Immunohistochemical analyses revealed abundant CB2 immunostaining in apparent neuronal and glial cells in a number of brain areas [37]. Previous studies have shown intense $\mathrm{CB} 1$ receptor immunoreactivity in hippocampal formation, basal ganglia and the molecular and granular layers of the cerebellum with moderate staining in the olfactory bulb, piriform cortex, cerebral cortex, and many thalamic nuclei $[38,39]$. Our data indicate that $\mathrm{CB} 1$ and $\mathrm{CB} 2$ immunoreactivities may share localization in the same brain structures with possible differences in the distribution patterns in neuronal elements where they are localized [37]. For example, these previous studies $[38,39]$ and our data show that both CB1 and CB2 receptors are localized in the cerebellum, where CB1 was seen in the molecular layer and granular layers whereas CB2 receptors were observed mainly in Purkinje cells and the molecular layer. In spite of the accumulating evidence using in situ hybridization, mRNA probes, specific CB2 
antibodies and data from our studies and those of others indicating the expression of $\mathrm{CB} 2$ receptors in the brain, much less is known about the specific cell types in which CB2 receptors are found and their subcellular localization in these cells in the brain remains to be determined. Such future studies will allow direct electrophysiological analysis for the definition of the specific roles of CB2 receptors in the brain.

The new knowledge from our data and those of other recent studies [4-12, 37, 40-42] that CB2 receptors are present in the brain raises many questions about the possible roles that $\mathrm{CB} 2$ receptors may play in the nervous system. These results therefore extend the previous evidence that $\mathrm{CB} 2$ receptors are playing an important role in immune function to other putative neuronal functions by their apparent presence in neuronal processes. Our studies implicate neuronal and glial CB2 receptors in the CMS model of depression and substance abuse. A possible direct involvement of neural mechanisms has been linked to $\mathrm{CB} 2$ receptor-mediated antihyperalgesia in rats and mice [42]. Furthermore, brain stem CB1 and CB2 receptors were demonstrated to be functionally coupled to inhibition of emesis in the ferret [40]. The immunohistochemical localization of CB2 receptors, when compared to the known $\mathrm{CB} 1$ receptor distribution in the brain, may be an indication of other putative functional roles of CB2 cannabinoid receptors in the brain and spinal cord. Therefore, both CB1 and CB2 receptors seem likely to work both independently and/or cooperatively in differing neuronal populations to regulate important physiological activities in the CNS. The precise nature of the effects of neuronal CB2 receptor activation remains to be determined. Recent preliminary data indicate that CB2 action in the brain can be unmasked to reveal catalepsy, which may be relevant to the psychoactive effects of CB2 receptor activation [43]. If it turns out that the effects of CB2 ligands can be unmasked to reveal psychoactivity, then activating $\mathrm{CB} 2$ receptors in the brain may produce psychoactive and nonbehavioral effects, like emesis [40].

From the CB2 cannabinoid receptor electron micrograph data presented here and from the immunohistochemical distribution patterns in the cerebellum, it can be postulated that the presence of iCB2 in Purkinje cell bodies and dendrites may be indicative of their mainly postsynaptic localization. This is because the dendritic trees arising from the Purkinje cells are positive for iCB2. However, these dendrites have been shown not to be immunostained for $\mathrm{CB} 1$ receptors confirming the presynaptic localization of $\mathrm{CB} 1$ receptors. As demonstrated in our study, the cell bodies of the Purkinje cells are immunoreactive for $\mathrm{CB} 2$ but negative for CB1 receptors as noted by others [38, 39], again confirming the established presynaptic localization of $\mathrm{CB} 1$ receptors in the brain. Another possibility is that $\mathrm{CB} 2$ cannabinoid receptors may be synthesized in the cell body of the Purkinje cells to be transported to another location. It has been documented that CB1 receptors are present in the axons coming from the basket cells located in the molecular layer that forms the basket cells around the basal area of the Purkinje cells $[38,39]$. The report [40] on the identification and functional characterization of brain stem cannabinoid CB2 receptors is consistent, in part, with our findings and with other reports of brain CB2 receptor expression [4-12, 30, 41]. However, a focus on brain stem localizations and antiemetic functions of brain cannabinoid CB2 receptors [40] may understate the importance of $\mathrm{CB} 2$ receptors in the other brain areas in which we and others have identified CB2 mRNA and protein. The previous interpretation was that because CB2 was not detected in the brain, it was enriched in the peripheral tissues, particularly in immune cells. Therefore, targeting $\mathrm{CB} 2$ receptors by specific CB2 ligands may result in therapeutic activity without psychoactivity. This conclusion may be valid for the wrong reasons. It appears that cannabinoids may have a more significant role in controlling neuroinflammation than previously thought [41]. Nevertheless, the distribution of $\mathrm{iCB} 2$ in the brain may provide novel targets for the effects of cannabinoids in the nervous system beyond neuroimmunocannabinoid activity.

\section{Overview of Brain CB2 Cannabinoid Receptors}

Variants of CB1 and CB2 Cannabinoid Receptor

Gene Structures

The CB2 cannabinoid gene structure has been poorly defined thus far, but we have extensively analyzed and characterized the human $C B 1$ gene and its $5^{\prime}$ exons, candidate regulatory regions, polymorphisms, haplotypes and association with polysubstance abuse [44]. The human $\mathrm{CB} 1$ receptor was found to have a number of splice variants, which may in part account for some of the myriad behavioral effects of marijuana and cannabinoid ligands, along with novel exons and candidate promoter region sequences that confer reporter gene expression. Interestingly, common polymorphisms reveal patterns of linkage disequilibrium and haplotype analysis that display significant allelic frequency differences between substance abusers and controls in European-American, African-American and Japanese samples [44]. The many splice variants of the $C B 1$ gene that we have reported in 
humans [44] probably account for the myriad behavioral effects of smoking marijuana (fig. 7a). Such effects may include actions at CB2 cannabinoid receptors because their presence has been poorly characterized and less well studied for CNS function. However, many features of the cannabinoid CB2 gene structure, regulation and variation are beginning to emerge with the discovery and functional identification of $\mathrm{CB} 2$ receptors in the mammalian CNS. This prior poor definition could be related to the previously held view that $C B 2$ gene was not expressed in the brain but mainly in immune cells and it was less investigated for roles in the CNS except for the association with brain cells of macrophage lineage.

The human CB2 gene and its mouse ortholog are located on chromosomes $1 \mathrm{p} 36$ and 4QD3, respectively. In humans, the CB2 gene is reported to consist of a single translated exon flanked by $5^{\prime}$ and $3^{\prime}$ untranslated regions [45], and a single untranslated exon and similar CB2 gene structure is shown in mice except that two transcripts are encoded using different first exons (fig. 7b, c). Most regions of the $C B 2$ gene are highly conserved, but the human has glutamine and mice and rats have arginine at position $63[45,46]$. Mice with deletion of the CB2 gene have a decreased bone mass, reminiscent of human osteoporosis [47] and in humans a number of polymorphisms in the CB2 gene including Q63R $[46,47]$ have been reported. H316Y has been linked to osteoporosis and autoimmune disorders. There is little or no information about the role of $\mathrm{CB} 2$ cannabinoid receptors in neuropsychiatric disorders. But in neurological disorders associated with inflammation, the expression of CB2 receptors has been reported in limited populations of microglia including plaque-associated glia in Alzheimer's disease brains $[29,30]$. Indeed our studies provide the first evidence for a role of CB2 cannabinoid receptors in depression and substance abuse as described below.

\section{Behavioral Evidence for the Functional Presence of}

CB2 Cannabinoid Receptors in the Brain

There are two currently well-characterized cannabinoid receptors and there is functional evidence for the existence of other subtypes of cannabinoid receptors [2]. Increasingly, functional evidence suggests that some cannabinoids mediate their effects independently of known CB1 and CB2 cannabinoid receptors. Thus, the cloning of an orphan G-protein-coupled cannabinoid receptor, GPR55, may be another subtype of cannabinoid receptors [48]. The initial characterization and functional distribution indicate that GPR55 may be present in several CNS cell types and its activation increases intracellular calci- um [48]. This putative human GPR55 cannabinoid receptor is encoded by 319 amino acids and was mapped to chromosome 2q37. Human GPR55 transcripts have been isolated from the brain and spleen, and specific mRNA is expressed in the caudate nucleus and putamen, but not in the hippocampus, thalamus, pons, cerebellum and frontal cortex of the brain or in the liver [49]. Curiously in rats, mRNA transcripts of the GPR55 ortholog have been detected in the spleen and intestine, and in situ hybridization has indicated some expression in the hippocampus, thalamic nuclei and midbrain regions [49]. So far, GPR55 orthologs have been identified in the genomes of the rat, mouse, dog, cow, chimpanzee and human. The mouse ortholog is located on chromosome 1 and encodes a 327-amino-acid protein. These currently known cannabinoid receptors include CB1, CB2, GPR55 and CBn (where $\mathrm{CBn}$ is any putative functional cannabinoid receptor subtype but without molecular identity; see Onaivi et al. [50] for a review).

In the behavioral studies, we used mice subjected to CMS and another group of mice that had been exposed to capsaicin, the pungent ingredient in hot 'chili' peppers. The involvement and expression of CB2 cannabinoid receptors in the brains of CMS and control mice was determined using Western blotting and RT-PCR (fig. 3 for RTPCR data). Anhedonia was established with a significant decrease in weekly sucrose and modification of alcohol consumption by animals subjected to CMS. CB2 cannabinoid receptors were found to be expressed in the brains of control mice and enhanced in the brains of CMS animals. Alcohol consumption was modified in the CMS animals compared to controls, and curiously that alcohol consumption in stressed mice was significantly enhanced by chronic treatment with the mixed CB1/CB2 agonist WIN55212-2 and JWH015, a putative CB2 cannabinoid receptor agonist, but not in control mice that were not subjected to CMS. This may not be surprising as

Fig. 7. The human $C B 1$ and $C B 2$ gene structures. a Structure of the $C B 1$ gene and its five variants that may account for numerous behaviors in the brain. The human CB2 gene and its mouse ortholog are located on chromosomes 1 p36 and 4QD3, respectively. In humans (b), the $C B 2$ gene consists of a single translated exon flanked by $5^{\prime}$ and $3^{\prime}$ untranslated regions, and a single untranslated exon and similar $C B 2$ gene structure is shown in mice except that two transcripts are encoded using different first exons (c). Most regions of the $C B 2$ gene are highly conserved, but the human has glutamine and mice and rats have arginine at position 63 . ESTs $=$ Expressed sequence tags. 


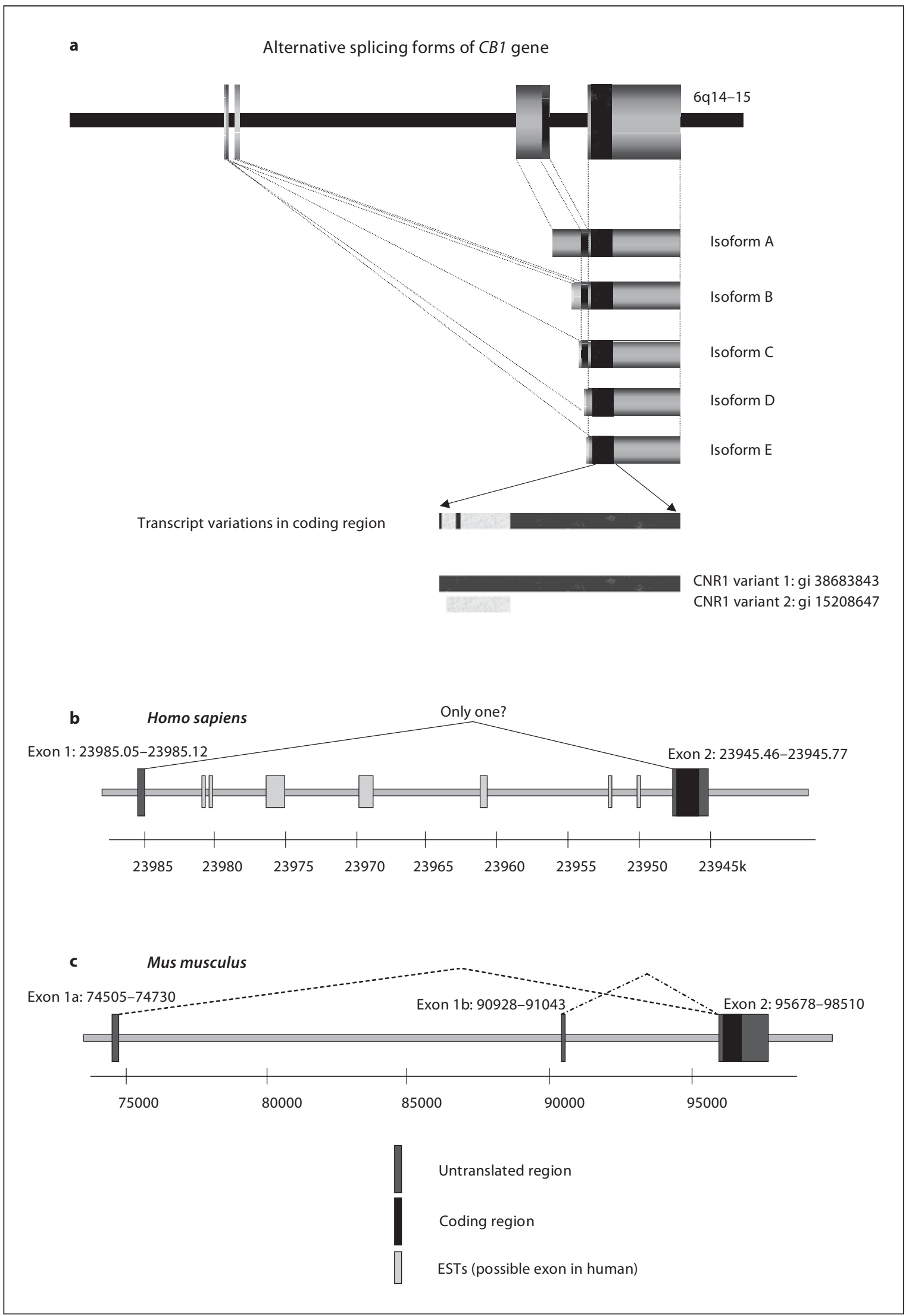


WIN55212-2, a pravadoline derivative, does not only activate and bind to $\mathrm{CB} 1$ but also $\mathrm{CB} 2$ cannabinoid receptors; however, it preferentially binds to $\mathrm{CB} 2$ receptors [27]. This is even more relevant as CB1 mutant mice still respond to WIN55212-2 but not $\Delta^{9}$-THC [51].

Indeed chronic unpredictable stress was shown to downregulate endocannabinoid signaling with reduced CB1 receptor expression and significantly reduced the content of the endocannabinoid 2-arachidonylglycerol within the hippocampus in the rat [52]. In another study, the differential responses to acute and repeated stress in newborn and adult cannabinoid CB1 receptor knockout mice provided additional evidence that the endocannabinoid physiological control system plays a vital role in the animal's ability to cope with stress during early development as well as in adulthood [53]. Furthermore, similarities between some symptoms of melancholic depression and those seen in animals with endocannabinoid deficiency as in CB1 mutant mice or those with pharmacological blockade of the $\mathrm{CB} 1$ receptors have also been reported [54]. Our data extend this deficiency in endocannabinoid signaling in the CMS model to the alteration of brain CB2 cannabinoid receptors that is a component of the endocannabinoid physiological control system. Taken together, with previous data demonstrating that CB1 knockout mice exhibit enhanced susceptibility to anhedonic effects of chronic variable stress [54], our data suggest a functional interaction with the endocannabinoid physiological control system, with a contribution from both CB1 and CB2 cannabinoid receptors in the CMS model of depression.

In our current studies, the chronic treatment of mice with the mixed $\mathrm{CB} 1$ and $\mathrm{CB} 2$ agonist WIN55212-2 blocked anhedonia induced by CMS. Similar results were obtained with the putative CB2 agonist, JWH015, also known to have effects on CB2 receptors [Onaivi et al., unpubl. data]. We have also evaluated the effects of the putative CB2 agonist, JWH015, the mixed CB1/CB2 agonist WIN55212-2 and the antagonist SR144528 on mouse general activity, including distance traveled, ambulatory activity and stereotype behavior. Stereotypy is the repetitive behaviors like rearing which are automatically assessed by the computer-controlled locomotor activity monitors. The performance of mice in the two-compartment black-and-white box was also assessed following acute treatment with the agonist JWH015 and the antagonist SR144528. Acute treatment with the CB2 agonist (JWH015) alters mouse spontaneous locomotor activities in a strain- and gender-dependent fashion. Increasing doses of JWH015 reduced activity in general. However, there was an increase in activity by the males and a reduction in activity by the females of the DBA/2 strain. The enhanced locomotor activity recorded in the DBA/2 males occurred at the lower doses of the agonist; however, a general pattern of depression in locomotor activity was induced by JWH015 in both males and females in the three mouse strains tested as the dose was increased up to $20 \mathrm{mg} / \mathrm{kg}$ (fig. 1). The effects of acute administration of JWH015 on stereotype behavior were similar to those described for locomotor activity with the females of the three strains C57BL/6, BALBc and DBA/2 more susceptible to the locomotor depressant effects. Similar observations have been reported for the effects of another CB2 agonist, GW405833 [55]. Curiously, the observation that CB2 agonists induce sedation and catalepsy only at higher doses has been interpreted by this group and others in rodent models of pain, to have a potential to treat pain without eliciting the centrally mediated side effects associated with nonselective cannabinoid agonists $[21,56]$. While this view may be speculative, the recent reports of the functional presence of $\mathrm{CB} 2$ cannabinoid receptors in the CNS may indicate that $\mathrm{CB} 2$ and $\mathrm{CB} 1$ cannabinoid receptors work independently and/or cooperatively in different neuronal populations to regulate a number of physiological activities influenced by cannabinoids.

The performance of mice in the two-compartment black-and-white box was also evaluated. The CB2 agonist reduced mouse general activity with increasing doses, demonstrating that JWH015 may inhibit mouse spontaneous locomotor activity, probably through activation of CB2 cannabinoid receptors. In the two-compartment black-and-white box, the acute effects of this putative CB2 agonist JWH015 at low doses (1-20 mg/kg) did not induce a robust anxiolytic response. Rather this peripheral administration of JWH015 induced an anxiogenic profile of response in the black-and-white test box with females of the C57BL/6 strain being more sensitive to aversions in the white chamber. In contrast, chronic treatment of control mice with JWH015 induced an anxiolytic profile of response in comparison to the CMS animals. The locomotor activities following the acute treatment with JWH015 by the female C57BL/6 mice in the white chamber was significantly reduced compared to the males without significant modification in the black chamber by both male and female C57BL/6 mice in comparison to vehicle-treated controls. However, the total zone entries into both chambers were significantly reduced with increasing dose, with the female mice being more susceptible to the locomotor depressant effects of JWH015. Using the DBA/2 strain, the spontaneous loco- 
motor activity and stereotype behavior were enhanced by acute administration of low doses of SR144528. The males were more susceptible to the enhanced locomotor behavior than the female mice, except at the $20 \mathrm{mg} / \mathrm{kg}$ dose when the male mice were also more sensitive to the locomotor depressant effects of CB2 cannabinoid receptor antagonism. SR144528 did not induce stereotype behavior in female mice at the doses used. In the two-compartment black-and-white test box, treatment with SR144528 had little or no effect on the time spent in both chambers by male or female DBA/2 mice except a reduced time spent in the white chamber by the male mice at the highest dose used of $20 \mathrm{mg} / \mathrm{kg}$. The spontaneous locomotor activities in both chambers by both DBA/ 2 males and females treated with SR144528 were also not significantly different from vehicle-treated control mice at $20 \mathrm{mg} / \mathrm{kg}$ when the locomotor activity was significantly reduced in the white chamber in comparison to control animals. The transition between the chambers measured as total zone entries was also not significantly different from control mice, except at the lowest dose of $1 \mathrm{mg} / \mathrm{kg}$ of SR 144528 when the transitions between the chambers were significantly enhanced in the male mice. We then determined the performance of the stressed animals in behavioral measures of these motor function and emotionality tests with and without challenge with the mixed CB1 and CB2 agonist WIN55212-2 or JWH015, the putative CB2 cannabinoid receptor agonist. Stress, whether by CMS or prenatal exposure to capsaicin, induced gender-specific aversions in the elevated plus-maze test and modulation of spontaneous locomotor activity in mice. While the modulation of locomotor activity induced in mice by stress was enhanced, the aversions of mice to the open arms of the plus-maze were reduced by treatment with WIN55212-2 [Onaivi et al., unpubl. data]. In contrast, the reduced spontaneous locomotor activities of mice subjected to CMS for 4 weeks were enhanced by acute or chronic daily treatment with the putative $\mathrm{CB} 2$ cannabinoid agonist (JWH015), in comparison to control mice that were not stressed but treated acutely or chronically with JWH015. On the other hand, stress and chronic treatment with JWH015 appeared to reduce stereotype response in control and stressed mice, while acute treatment significantly reduced stereotype behavior in stressed but not in control animals (fig. 2). These effects of CB2 cannabinoid receptor ligands in in vivo behavioral tests are provided as functional evidence of $\mathrm{CB} 2$ cannabinoid receptors in the brain that play a role in motor function and emotionality tests. The antagonism of the behavioral effects of the putative $\mathrm{CB} 2$ receptor agonist, JWH015, by
SR144528 was not determined in this study. However, other studies havedemonstrated the selectivity ofJWH015 on mediating its effects via $\mathrm{CB} 2$ receptors $[57,58]$ and the effect of JWH015 was completely blocked by the CB2specific antagonist, SR144528 [59].

CB2 Cannabinoid Receptor Gene Targeting by CB2

Antisense Oligonucleotide Modifies Behavior

We speculated that if CB2 cannabinoid receptors are present in the brain, then antisense oligonucleotides complementary to $C B 2$ mRNA transcript will block translation of or stimulate degradation of $C B 2$ mRNA. It is therefore important to determine whether inhibition of CB2 gene expression in the brain will alter behavior as observed with the exogenous administration of CB2 ligands discussed above. Although antisense technologies have limitations, with appropriate controls and modifications, an antisense drug for human use is available in the clinic [55]. The validated plus-maze test of anxiety [60, 61] was used to ascertain whether CB2 cannabinoid transcripts are functionally expressed in the brain to influence behavior. An underlying hypothesis for this test is the self-medication hypothesis that an affective syndrome, including stress associated with everyday living, depression and anxiety states may be associated with uncontrollable drug and alcohol dependency. Thus the plusmaze test that has been validated for use as a model for assessment of anxiety was utilized in the determination of a functional role (if any) of CB2 cannabinoid receptors in the brain. The plus-maze consists of two enclosed arms and two open arms and the test is based on rodents' aversion to open spaces. Standard anxiolytic drugs such as diazepam reduce the aversions to the open arms by increasing the time spent and number of entries into the open arms. Direct intracerebroventricular cannabinoid CB2 oligonucleotide microinjection into the mouse brain reduced mouse aversions to the open arms, further indicating the functional presence of $\mathrm{CB} 2$ cannabinoid receptors in the brain influencing behavior.

Functional Presence and CB2 Cannabinoid Gene Transcript Variation in Brains of Stressed Animals and Animals Treated with Abused Substances

We first determined whether $C B 2$ gene transcripts are present in the brain and then compared the expression of CB2 gene transcripts between the spleen and the brain. This is because CB2 receptor mRNA was thought to be expressed primarily in immune cells but not in the brain and that the message was most abundant in B cells [18-20, $46,62,63]$. Since CB2 receptors are intensely expressed in 
peripheral and immune tissues, expression in brain microglia has been anticipated. We found that the expression of $C B 2$ gene transcripts was about 100 times higher in the spleen than in the brain of rats using RT-PCR. Therefore brain cells, neurons plus glial cells, express mRNA for CB2 gene transcripts but at lower levels than peripheral tissues and immune tissues. Differences in the distribution of mouse, rat, and human $[3,46]$ CB2 cannabinoid receptors have been reported, but in all cases these investigators could not detect $\mathrm{CB} 2$ receptors or their gene transcripts in the brain. We have previously demonstrated the differential expression of $C B 1$ gene transcripts in different mouse strains $[2,50]$. Using CB2-specific probes and primers, we compared the expression of $C B 2$ gene transcripts in three mouse strains, BALBc, DBA/2 and C57BL/6, for which we had previously reported the differential strain-specific brain distribution of $C B 1$ gene transcripts [2]. The expression of the $C B 2$ gene transcripts was present but varied insignificantly in the whole brains of these mouse strains and was enhanced insignificantly by CMS (fig. 3). Furthermore, the expression of the $C B 1$ and $C B 2$ cannabinoid receptor gene transcripts was compared in different regions of the mouse brain. The data obtained confirmed the previously known distribution patterns of $C B 1$ gene transcripts enriched in the cerebellum, hippocampus, striatum, thalamus, cortex, hypothalamus, brain stem, midbrain, and testis. The expression levels of the $C B 1$ gene as shown in a representative RT-PCR were 100 times higher than the CB2 gene expression levels with reference to the brain stem. The spleen is known to have the most abundant $C B 2$ gene transcripts. Substantial detection of $C B 2$ gene transcripts was recorded in the stomach, brain stem, testis, lungs, kidney, heart, and hypothalamus. To further understand the physiological relevance of the expression of $\mathrm{CB} 2$ cannabinoid receptors and their gene transcripts, we examined the expression of $C B 2$ gene transcripts in rodents treated with opioids, morphine or heroin, cocaine and alcohol in comparison to saline-treated controls. Animals treated with cocaine or heroin showed increased expression of $C B 2$ gene transcripts in comparison to saline-treated controls. The modification of expression of $C B 2$ gene transcripts is notable, indicating the presence of $C B 2$ gene transcripts in the brain that is influenced by abused substances and stress.

CB2 Cannabinoid Receptor Gene Variation in Depression and Substance Abuse: from Mice to Humans

Reports by our group [4-12] and others [40-42] have identified the functional presence of cannabinoid CB2 receptors in neuronal and glial processes contrary to the view for over a decade that the CB2 cannabinoid receptors were restricted to peripheral tissues and predominantly immune tissues. We also found differential modification of CB2 gene expression in various brain regions of animals treated with abused substances like cocaine, morphine and alcohol and in those subjected to stressors, including CMS and prenatal capsaicin exposure [4-12]. These findings are of importance as they open new areas in basic neuroscience research and provide new approaches for our fundamental understanding of depression and addictive disorders, for which pharmacological treatment has been disappointing. We have tested the hypothesis that genetic variants of the CB2 gene might have significant effects and be associated with depression and alcoholism. This hypothesis is supported by the identification of a missense polymorphism at CB2 CDNA position 188-189, which results in a dinucleotide conversion of AA to GG and predicts a nonconservative amino acid substitution of glutamine by arginine at position 63 (Q63R). This tandem polymorphism is important as it has the potential to change function in the mature expressed cannabinoid CB2 receptor as demonstrated in the immune system by an in vitro assay [55]. In humans, the Q63R polymorphism has been associated with osteoporosis and autoimmune disorders [45, 47]. The association of $C B 2$ gene variation was probed in Japanese subjects to examine the nonsynonymous polymorphism, Q63R, in the CB2 gene for association with depression or alcoholism in the Japanese population. There was a significant difference in allelic frequency between cases and controls at the Q63R polymorphism in the CB2 gene [Ishiguro, unpubl. data], and a high incidence of this polymorphism was found in Japanese alcoholics and depressed subjects. As many genetic variants play various roles in depression and/or substance abuse, the Q63R polymorphism may be a previously unknown risk factor in depression and/or alcoholism at least in the Japanese population. If this can be generalized to other ethnicities, then the results support the possibility of targeting the cannabinoid system using CB2 ligands in depression and drug abuse and perhaps in their comorbidity in Japanese or other populations. In the mouse model, the CB2 receptor and transcripts were regulated insignificantly by chronic mild stressors. Chronic treatment with the mixed CB1/CB2 agonist WIN55212-2 (1.0 mg/day) or the putative CB2 agonist JWH015 $(20 \mathrm{mg} / \mathrm{kg})$ enhanced alcohol consumption in stressed but not in control mice. In animals that developed alcohol preference, $C B 2$ gene expression was downregulated in the midbrain and striatum. It 
is therefore tempting to speculate that the reported effects of alcohol may be associated with changes in the cannabinoid system, with CB2 cannabinoid receptors playing a regulatory role.

CB2 Receptor Immunohistochemical Localization in the Rat Brain and Spleen

Contrary to prior reports that $\mathrm{CB} 2$ cannabinoid receptors were not expressed in the brain, we report wide distribution of CB2 receptors in brain regions suggesting a reevaluation of the role of $\mathrm{CB} 2$ cannabinoid receptors in the CNS $[4-12,37]$. Other reports have appeared indicating the functional presence in the brain stem [40] and localization in the rat cerebellum [42] in agreement with our reports $[4-12,37]$. These reports all show the absence of CB2 mRNA in CB2 knockout mice and the presence in wild-type controls. Immunoblots from mouse brain and spleen lysates revealed a major band of approximately $53 \mathrm{kDa}$, with other visible bands around $37 \mathrm{kDa}$ and $75 \mathrm{kDa}$, similar to those observed recently [40]. The use of three anti-CB2 affinity-purified polyclonal antibodies with peptide conjugates corresponding to different amino acid terminals and yielding similar patterns of staining indicated further specificity of CB2 receptor localization. The different antibodies showed very similar staining patterns in both the rat spleen and cerebellum sections supporting their specificity to the CB2 receptor. Cannabinoid CB2 immunostaining was observed in many parts of the rat and mouse CNS. Most iCB2 was found in patterns consistent with nerve cell bodies, neuronal processes, and glial cells and processes. The 3rd CB2 receptor antibody was utilized for the CB2 knockout mice and their wild-type controls. This 3rd antibody appeared more specific for mouse CB2 receptors and has an origin different from the first two antibodies that were initially utilized in the preliminary studies. The preadsorption and coincubation of the antibody with the immunizing peptide resulted in blocking CB2 staining in the rat hippocampus, hippocampal cell culture, HEK 293 cells transfected with pcDNA $3.1 \mathrm{CB} 2$ and a lack of $\mathrm{iCB} 2$ in HEK cells with pcDNA 3.1 mock transfection. Using the CB2 knockout mice, $\mathrm{CB} 2$ immunostaining was present in the spleen of wild-type but not in the spleen of CB2 knockout mice. CB2 immunostaining was detected in the interpolar part of the spinal 5th nucleus of wild-type but not CB2 knockout mice. As an additional control, using in situ hybridization, we demonstrated that $C B 2$ cannabinoid receptor mRNA was clearly expressed in the cerebellum of wild-type and not in the CB2 knockout mice.
CB2 receptor mRNA was also absent using the sense controls in the wild-type mice. Antisense cRNA probe did not detect signals around the Purkinje cells and molecular layer in the CB2 knockout mice. However, strong signals were detected around the Purkinje cells and molecular layers with little or no expression in the granular layer of the cerebellum in the wild-type mice. Specifically these studies and our initial RT-PCR analyses of brain CB2 mRNAs of naïve and drug-treated mice [12] revealed brain $C B 2$ receptor gene transcript expression at levels much lower than those of the spleen further indicating the presence of $\mathrm{CB} 2$ receptors in the brain. The spleen CB2 gene expression using RT-PCR was about 140 times higher than that in the brain. CB2 receptor gene expression was also detected in the mouse striatum, midbrain and hippocampus at about the same expression levels. Using double-labeling sequentially, tissues were first labeled with the CB2 receptor antibody, followed by a neuron marker, NSE. Confocal immunofluorescence image of $\mathrm{iCB} 2$, NSE on neurons and overlay of $\mathrm{CB} 2$ receptor on neurons illustrate the presence of $\mathrm{CB} 2$ receptors on hippocampal neurons in culture. $\mathrm{ICB} 2$ was also observed in the olfactory tubercle, islands of Calleja, cerebral cortex, striatum, thalamic nuclei, hippocampus, amygdala, substantia nigra, periaqueductal gray, paratrochlear nucleus, paralemniscal nucleus, red nucleus, pontine nuclei, inferior colliculus and the parvicellular portion of the medial vestibular nucleus [37]. CB2-immunopositive staining was observed in the regions of the cerebral cortex that were analyzed (fig. 4). Apical dendrites of pyramidal neurons were moderately to heavily stained. Other less heavily stained neurons and many blood cells do not show immunostaining. A moderate to dense CB2 immunostaining was observed in pyramidal neurons of the hippocampal allocortex and some interneurons in the stratum oriens and stratum radiatum (fig. 5). Some glial cells also appeared to be immunostained for $\mathrm{CB} 2$ in the hippocampus (fig. 5). Therefore, CB2 cannabinoid receptors are widely distributed in the brain areas examined.

Ultrastructural and Subcellular Localization of CB2

Receptors in Mouse Cortical Neurons

Definitive electron microscopic evidence is needed to precisely determine the subcellular localization of CB2 receptors. The immunoelectron microscopy approach shows a high-resolution definition of cortical CB2 cannabinoid receptor localization at the ultrastructural level. Electron micrographs from different cortical areas show dendrites with immunostaining for CB2 receptors with 
diffuse black deposits and mitochondria clearly visible. In some areas, axon terminals were not immunoreactive for CB2 receptors and small rounded synaptic vesicles were seen. Two axon terminals making contact with a dendrite but without immunostaining for CB2 are shown in figure 6 . The pattern of staining in most cortical areas appears to be mainly postsynaptic localization of CB2 cannabinoid receptors. For example at the area of the two synaptic contacts seen in figure 6 , the synapses appear to be excitatory and possibly glutamatergic. These data are preliminary and we cannot exclude that some of the CB2 receptors may be presynaptic, just like $\mathrm{CB} 1$ receptors are not exclusively presynaptic in the brain. CB1 receptors are known to be mainly presynaptic in the CNS where cannabinoids act at presynaptic CB1 receptors and endocannabinoids have emerged as one of the classes of retrograde messengers involved in the regulation of synaptic transmission. The functional implication of pre- and/or postsynaptic localization of $\mathrm{CB} 2$ cannabinoid receptors awaits further electrophysiological investigation and image analysis of this interesting component of the endocannabinoid physiological control system.

\section{Acknowledgments}

I am indebted to my collaborators across the globe without whom this work and report would have been impossible: Dr. Ishiguro and his team at Tsukuba University in Japan, Dr. Brusco and her team in Argentina as well as Dr. Tagliaferro who has now relocated to Dr. Morale's laboratory in NIDA-NIH, Baltimore, Md., USA, Dr. Akinshola at Howard University in Washington, D.C., USA, Dr. Fride from the College of Judea and Samaria in Israel, Dr. Thiebot in Pitié-Salpêtrière in France, Dr. Uhl and his team in NIDA-NIH, Baltimore, USA where I am a visiting scientist and my students and postdocs, past and present and my colleagues at William Paterson University, Wayne, N.J., USA. Specifically, I would like to thank Drs. Jane Voos, Steve Vail, Michael Peek and Anita Brandolini for help with the grammar. I also acknowledge financial support from William Paterson University center for research, the Dean, Dr. Sandra DeYoung for continued student worker support and the Provost office for release time. I am enormously thankful to Dr. Fridolin Sulser who paid special attention to guide my career when I was a research Professor at Vanderbilt University in Nashville, Tenn., USA. The CB2 knockout and their wild-type control mice used in our study were developed by Buckley et al. [64], and obtained from the National Institutes of Health through Dr. George Kunos of the NIAAANIH, USA.

\section{References}

-1 Matsuda LA, Lolait TI, Bownstein MJ, Young AC, Bonner TI: Structure of a cannabinoid receptor and functional expression of the cloned cDNA. Nature 1990;346:561-564.

2 Onaivi ES, Ishiguro H, Lin Z, Akinshola BE, Zhang PW, Uhl GR: Cannabinoid receptor genetics and behavior; in Onaivi ES (ed): Biology of Marijuana: From Gene to Behavior. Boca Raton, Taylor and Francis, 2002, pp 144.

3 Munro S, Thomas KL, Abu-Shaar M: Molecular characterization of a peripheral receptor for cannabinoids. Nature 1993;365:6165.

4 Meozzi PA, Patel S, Myers L, Leonard CM, Gardner E, Onaivi ES: Decreased alcohol consumption and enhanced cannabinoid CB2 receptor expression in mouse chronic mild stress model of depression. 7th Annu Undergraduate Res Symp Chem Biol Sci, Baltimore, 2004

5 Onaivi ES, Ishiguro H, Patel S, Meozzi PA, Myers L, Tagliaferro P, Leonard CM, Gardner E, Brusco A, Akinshola BE, Liu QR, Hope B, Uhl GR: Presence and functional expression of peripheral cannabinoid CB2 receptors in the brain. Coll Probl Drug Depend Annu Meet, Orlando, 2005.
6 Onaivi ES, Ishiguro H, Gong JP, Patel S, Meozzi PA, Myers L, Tagliaferro P, Leonard CM, Gardner E, Brusco A, Akinshola BE, Liu QR, Hope B, Uhl GR: Peripheral cannabinoid CB2 receptors are expressed in the brain and involved in depression and substance abuse. ICRS Symp Cannabinoids, Vermont, 2005, p 66.

7 Onaivi ES, Ishiguro H, Gong JP, Patel S, Meozzi PA, Myers L, Mora Z, Perchuk P, Tagliaferro P, Leonard CM, Gardner E, Brusco A, Akinshola BE, Liu QR, Hope B, Uhl GR: Presence and functional expression of CB2 cannabinoid receptors in brain that is involved in depression and substance abuse. Int Soc Neurochem/Eur Soc Neurochem Satellite Meet, Isola di San Servolo, Venice, 2005.

8 Gong JP, Onaivi ES, Uhl GR: Cannabinoid CB2 receptors: immunohistochemical localization in rat brain. ICRS Symp Cannabinoids, Vermont, 2005, p 91.

9 Onaivi ES, Ishiguro H, Gong JP, Patel S, Meozzi PA, Myers L, Mora Z, Perchuk P, Tagliaferro P, Leonard CM, Gardner E, Brusco A, Akinshola BE, Liu QR, Hope B, Uhl GR: Presence and functional expression of $\mathrm{CB} 2$ cannabinoid receptors in the brain that is involved in depression and substance abuse. Int Narc Res Soc Meet, Annapolis, 2005.
10 Gong JP, Onaivi ES, Uhl GR: Peripheral cannabinoid CB2 receptors: expression in neuronal patterns and localization in rat brain. Int Narc Res Soc Meet, Annapolis, 2005.

11 Onaivi ES, Ishiguro H, Gong JP, Patel S, Meozzi PA, Myers L, Mora Z, Perchuk P, Tagliaferro P, Leonard CM, Gardner E, Brusco A, Akinshola BE, Liu QR, Hope B, Uhl GR: Discovery of the presence and functional expression of CB2 cannabinoid receptors in brain that is involved in depression and substance abuse. Soc Neurosci Abstr, Washington, 2005.

12 Onaivi ES, Ishiguro H, Patel S, Meozzi PA, Myers L, Tagliaferro P, Hope B, Leonard CM, Uhl GR, Brusco A, Gardner E: Methods to study the behavioral effects and expression of CB2 cannabinoid receptors and its gene transcripts in chronic mild stress model of depression; in Onaivi ES (ed): Marijuana and Cannabinoid Research: Methods and Protocols. Totowa, Humana Press Inc, 2006, pp 291-298.

13 Berdyshev EV: Cannabinoid receptors and the regulation of immune response. Chem Phys Lipids 2000;108:169-190.

14 Suigiura T, Waku K: 2-Arachidonoylglycerol and cannabinoid receptors. Chem Phys Lipids 2000;108:89-106. 
15 Wilson RI, Nicoll R: Endogenous cannabinoids mediate retrograde signaling at hippocampal synapses. Nature 2001;410:588-592.

-16 Carlisle SJ, Marciano-Cabral F, Staab A, Ludwick C, Cabral GA: Differential expression of the CB2 cannabinoid receptor by rodent macrophages and macrophage-like cells in relation to cell activation. Int J Immunopharmacol 2002;2:69-82.

17 Derocq JM, Segui M, Marchand J, Le Fur G, Casellas P: Cannabinoids enhance human $B$-cell growth at low nanomolar concentrations. FEBS Lett 1995;369:177-182.

18 Galiegue S, Mary S, Marchand J, Dussossoy D, Carriere D, Carayon P, Bouaboula M, Shire D, Le Fur G, Casellas P: Expression of central and peripheral cannabinoid receptors in human immune tissues and leukocyte subpopulations. Eur J Biochem 1995;232: 54-61.

$\checkmark 19$ Griffin G, Wray EJ, Tao Q, McAllister SD, Rorrer WK, Aung M, Martin BR, Abood M: Evaluation of the cannabinoid CB2 receptorselective antagonist, SR144528: further evidence for CB2 receptor absence in the rat central nervous system. Eur J Pharmacol 1999;377:117-125.

-20 Shatz AR, Lee M, Condie RB, Pulaski JT, Kaminski NE: Cannabinoid receptors CB1 and CB2: a characterization of expression and adenylate cyclase modulation within the immune system. Toxicol Appl Pharmacol 1997; 142:278-287.

-21 Ibrahim M, Deng H, Zvonok K, Cockayne DA, Kwan J, Mata HP, Vandrah TW, Lai J, Porreca F, Makriyannis A, Malan TP: Activation of CB2 cannabinoid receptors by AM1241 inhibits experimental neuropathic pain: pain inhibition by receptors not present in the brain. Proc Natl Acad Sci USA 2003;100:10529-10533.

22 Kearn CS, Hilliard CJ: Rat microglial cell expresses the peripheral-type cannabinoid receptor (CB2) which is negatively coupled to adenylyl cyclase. ICRS Symp Cannabinoids, Vermont, 1997, p 61.

-23 Skaper SD, Buriani A, Dal Toso R, Petrelli L, RomanelloS, Facci L, Leon A: The ALIAmide palmitoylethanolamide and cannabinoids, but not anandamide, are protective in a delayed postglutamate paradigm of excitotoxic death in cerebral granule neurons. Proc Natl Acad Sci USA 1996;93:3984-3989.

-24 Facci L, Dal Toso Romanello S, Buriani A, Skaper SD, Leona A: Mast cells express a peripheral cannabinoid receptor with differential sensitivity to anandamide and palmitoylethanolamide. Proc Natl Acad Sci USA 1995;92:3376-3380.

-25 Samson MT, Small-Howard A, Shimoda LMN, Koblan-Huberson M, Stokes AJ, Turner H: Differential roles of CB1 and CB2 cannabinoid receptors in mast cells. J Immunol 2003; 170:4953-4962.
26 Lu Q, Straiker A, Lu Q, Maguire G: Expression of CB2 cannabinoid receptor mRNA in adult rat retina. Vis Neurosci 2000;17:9195.

27 Sheng WS, Hu S, Min X, Cabral GA, Lokensgard JR, Peterson PK: Synthetic cannabinoid WIN55212-2 inhibits generation of inflammatory mediators by IL-1beta-stimulated human astrocytes. Glia 2005;49:211-219.

28 Benito C, Kim WK, Chavarria I, Hillard CJ, Mackie K, Tolon RM, Williams K, Romero J: A glial endogenous cannabinoid system is upregulated in the brains of macaques with simian immunodeficiency virus-induced encephalitis. J Neurosci 2005;25:25302536.

29 Nunez E, Benito C, Pazos MR, Barbachano A, Fajardo O, Gonzalez S, Tolon RM, Romero J: Cannabinoid CB2 receptors are expressed by perivascular microglia cells in the human brain: an immunohistochemical study. Synapse 2004;53:208-213.

30 Pazos MR, Nunez E, Benito C, Tolon RM, Romero J: Role of the endocannabinoid system in Alzheimer's disease: new perspectives. Life Sci 2004;75:1907-1915.

31 Golech SA, McCarron RM, Chen Y, Bembry J, Lenz F, Mechoulam R, Shohami E, Spatz M: Human brain endothelium: coexpression and function of vanilloid and endocannabinoid receptors. Brain Res Mol Brain Res 2004;132:87-92.

-32 Ben-Shabat S, Fride E, Sheskin T, Tsippy T, Rhee MH, Vogel Z, Bisogno T, De Petrocellis L, Di Marzo V, Mechoulam R: An entourage effect: inactive endogenous fatty acid glycerol esters enhance 2-arachidonyl-glycerol cannabinoid activity. Eur J Pharmacol 1998; 353:23-31

33 Benito C, Nunez E, Tolon RM, Carrier EJ, Rabano A, Hillard CJ, Romero J: Cannabinoid CB2 receptors and fatty acid amide hydrolase are selectively overexpressed in neuritic plaque-associated glia in Alzheimer's disease brains. J Neurosci 2003;23:1113611141.

34 Chakrabarti A, Rossby SP, Manier DH, Perrin C, Onaivi ES, Sulser F: Molecular correlates of a chronic mild stress model of depression. Abstr Soc Neurosci 1996;22:2060.

35 Willner P: Chronic mild stress (CMS) revisited: consistency and behavioural-neurobiological concordance in the effects of CMS. Neuropsychobiology 2005;52:90-110.

36 Franklin KBJ, Paxinos G: The Mouse Brain in Stereotaxic Coordinates. San Diego, Academic Press, 1997.

- 37 Gong JP, Onaivi ES, Ishiguro H, Liu QR, Tagliaferro P, Brusco A, Uhl GR: Cannabinoid CB2 receptors: immunohistochemical localization in rat brain. Brain Res 2006; 1071:10-23.

- 38 Pettit DA, Harrison MP, Olson JM, Spencer RF, Cabral GA: Immunohistochemical localization of the neural cannabinoid receptor in rat brain. Neurosci Res 1998;51:391342 .
39 Tsou K, Brown S, Sanudo-Pena MC, Mackie $\mathrm{K}$, Walker JM: Immunohistochemical distribution of cannabinoid CB1 receptors in the rat central nervous system. Neuroscience 1998;83:393-411.

40 Van Sickle MD, Duncan M, Kingsley PJ, Mouihate A, Urbani P, Mackie K, Stella N, Makriyannis A, Piomelli D, Davison JS, Marnett LJ, Di Marzo V, Pittman QJ, Patel $\mathrm{KD}$, Sharkey KA: Identification and functional characterization of brainstem cannabinoid CB2 receptors. Science 2005;310:329332.

41 Ashton JC, Friberg D, Darlington CL, Smith PF: Expression of the cannabinoid CB2 receptor in the rat cerebellum: an immunohistochemical study. Neurosci Lett 2005;396: 113-116.

42 Beltramo M, Bernardini N, Bertorelli R, Campnella M, Nicolussi E, Fredduzzi S, Reggiani A: CB2 receptor-mediated antihyperalgesia: possible direct involvement of neural mechanisms. Eur J Neurosci 2006;23:15301538 .

43 Little P, Stabley GJ, Worm K, Sauei CT, Zhou Q, Conway-James N: Detection of cataleptic effects of selective CB2 receptor agonist in rats. CPDD Abstract 2006:470.

44 Zhang PW, Ishiguro H, Ohtsuki T, Carillo F, Walther D, Onaivi ES, Arinami T, Uhl GR: Human cannabinoid receptor 1: $5^{\prime}$ exons, candidate regulatory regions, polymorphisms, haplotypes and association with polysubstance abuse. Mol Psychiatry 2004;9: 916-931.

45 Sipe JC, Arbour N, Gerber A, Beutler E: Reduced endocannabinoid immune modulation by a common cannabinoid 2 (CB2) receptor gene polymorphism: possible risk for autoimmune disorders. J Leukoc Biol 2005; 78:231-238.

46 Brown SM, Wagner-Miller J, Mackie K: Cloning and molecular characterization of the rat $\mathrm{CB} 2$ cannabinoid receptor. Biochim Biophys Acta 2002;1576:255-264.

47 Karsak M, Cohen-Solal M, Freudenberg J, Ostertag A, Morieux C, Kornak U, Essig J, Erxlebe E, Bab I, Kubisch C, de Vernejoul MC, Zimmer A: Cannabinoid receptor type 2 gene is associated with human osteoporosis. Hum Mol Genet 2005;14:3389-3396.

48 Lauckner JE, Reyes F, Xu C, Hille B, Stella N, Mackie K: Distribution and functional characterization of a novel cannabinoid receptor. Soc Neurosci Abstr, Washington, 2005.

49 Sawzdargo M, Nguyen T, Lee DK, Lynch KR, Cheng R, Heng HHQ, George SR, O’Dowd BF: Identification and cloning of three novel human $G$ protein-coupled receptor genes GPR52, GPR53 and GPR55: GPR55 is extensively expressed in human brain. Brain Res Mol Brain Res 1999;64:193-198. 
50 Onaivi ES, Ishiguro $\mathrm{H}$, Zhang PW, Lin Z, Akinshola BE, Leonard CM, Chirwa SS, Gong JP, Uhl GR: Endocannabinoid receptor genetics and marijuana use; in Onaivi ES, Sugiura T, Di Marzo V (eds): Endocannabinoids: The Brain and Body's Marijuana and beyond. Boca Raton, Taylor \& Francis, 2006, pp 57-118.

-51 Di Marzo V, Breivogel CS, Tao Q, Bridgen DT, Razdan RK, Zimmer AM, Zimmer A, Martin BR: Levels, metabolism, and pharmacological activity of anandamide in $\mathrm{CB}(1)$ cannabinoid receptor knockout mice: evidence for non- $\mathrm{CB}(1)$, non- $\mathrm{CB}(2)$ receptormediated actions of anandamide in mouse brain. J Neurochem 2000;75:2434-2444.

- 52 Hill MN, Patel EJ, Carrier EJ, Rademacher DJ, Ormerod BK, Hillard CJ, Gorzalka BB: Downregulation of endocannabinoid signaling in the hippocampus following chronic unpredictable stress. Neuropsychopharmacology 2004;30:508-511.

-53 Fride E, Suris R: Differential response to acute and repeated stress in cannabinoid CB1 receptor knockout newborn and adult mice. Behav Pharmacol 2005;16:431-471.

54 Hill MN, Gorzalka BB: Is there a role for the endocannabinoid system in the etiology and treatment of melancholic depression. Behav Pharmacol 2005;16:333-352.
5 Valenzano KJ, Tafasse L, Lee G, Harrison JE, Boulet JM, Gottshall SL, Mark L, Pearson MS, Miller W, Shan S, Rabadi L, Rotshteyn Y, Chaffer SM, Turchin PI, Elsemore Y, Toth M, Koetzner L, Whiteside GT: Pharmacological and pharmacokinetic characterization of the cannabinoid receptor 2 agonist, GW405833, utilizing rodent models of acute and chronic pain, anxiety, ataxia and catalepsy. Neuropharmacology 2005;48:658672.

56 Kurreck J: Antisense technologies. Improvement through novel chemical modifications. Eur J Biochem 2003;270:1628-1644.

57 Nieri P, Greco R, Adinolfi B, Breschi MC, Martinotti E, Nannetti C, Podesta A: CB1and CB2-cannabinoid receptor-independent lipolysis induced by WIN 55,212-2 in male rat adipocytes. Naunyn Schmiedebergs Arch Pharmacol 2003;368:352-359.

-58 Ehrhart J, Obregon D, Mori T, Hou H, Sun N, Bai Y, Klein T, Fernandez F, Tan J, Shytle RD: Stimulation of cannabinoid receptor 2 (CB2) suppresses microglial activation. J Neuroinflammation 2005;2:29.

59 Zhong L, Geng L, Njie Y, Feng W, Song ZH: CB2 cannabinoid receptors in trabecular meshwork cells mediate JWH015-induced enhancement of aqueous humor outflow facility. Invest Ophthalmol Vis Sci 2005;46: 1988-1992.
60 Pellow S, Chopin P, File SE, Briley M: Validation of open:closed arm entries in an elevated plus-maze as a measure of anxiety in the rat. J Neurosci Methods 1985;14:149-167.

61 Lister RG: The use of a plus-maze to measure anxiety in the mouse. Psychopharmacology 1987;92:180-185.

62 Klein TW, Newton C, Larsen K, Lu L, Perkins I, Nong L: The cannabinoid system and immune modulation. J Leukocyte Biol 2003; 74:486-496.

63 Lee SF, Newton C, Widen R, Friedman H, Klein TW: Differential expression of cannabinoid $\mathrm{CB} 2$ receptor mRNA in mouse immune cell subpopulation and following B cell stimulation. J Pharmacol 2001;423:235-241.

64 Buckley NE, McCoy KL, Mezey E, Bonner T, Zimmer A, Felder CC, Glass M, Zimmer A: Immunomodulation by cannabinoids is absent in mice deficient for the cannabinoid CB2 receptor. Eur J Pharmacol 2000;396: 141-149. 